\title{
Respons Pertumbuhan dan Produksi Tanaman Cabai Keriting (Capsicum annuum L.) terhadap Aplikasi Pupuk Kompos dan Pupuk Anorganik di Polibag
}

\author{
Growth and Yield on Chili (Capsicum annuum L.) Effect of Compost and Inorganic \\ Fertilizer in Polybag
}

\author{
Hapsoh $^{1 *}$, Gusmawartati ${ }^{1}$, Al Ichsan Amri ${ }^{1}$ dan Asty Diansyah ${ }^{2}$
}

Diterima 14 September 2016/Disetujui 25 Oktober 2017

\begin{abstract}
The aim of the research was to determine growth and yield of chili (Capsicum annuum L.) as a result of application of compost and inorganic fertilizer. The research was conducted in experimental field at Jl. Melati Panam and soil laboratory Faculty of Agriculture, Riau University on Bina Widya Campus Km 12.5 Simpang Baru sub-district, Tampan district, Pekanbaru, from September 2015 to March 2016. Research used Completely Randomized Design (CRD) factorial consisting of two factors. The first factor was compost (K) : without compost, compost TKS (oil palm fruit branch + restaurant trash) and JRM (rice straw + market trash) $25 \mathrm{~g}$ polybag $^{-1}$ and the second factor was NPK dose $\left(0,12.5\right.$ and 25) $\mathrm{g}$ plant $^{-1}$.The variables observed were plant height, stem diameter, days to flowering, harvest date, length and weight of fruit per plant. Data obtained from the research were analyzed by analysis of variance followed by Duncan Multiple Range Test at 5\%. The results of application of compost with NPK did not show significant effect on plant height, length and weight of the fruit crop, but gave significant effect on stem diameter, harvest and flowering date.
\end{abstract}

Keywords: dose, NPK, plant growth, yield

\begin{abstract}
ABSTRAK
Penelitian ini bertujuan untuk mengetahui pertumbuhan dan hasil tanaman cabai (Capsicum annuит L.) terhadap aplikasi pupuk kompos dan pupuk anorganik. Penelitian dilaksanakan di Kebun Percobaan Jl. Melati Panam dan Laboratorium Tanah Fakultas Pertanian Universitas Riau Kampus Bina Widya Km 12.5 Kelurahan Simpang Baru, Kecamatan Tampan, Pekanbaru, sejak bulan September 2015 sampai Maret 2016. Penelitian dilaksanakan dengan Rancangan Acak Lengkap (RAL) yang disusun secara faktorial dan terdiri atas 2 faktor. Faktor pertama ialah percobaan pemberian pupuk kompos (K), terdiri dari tanpa pupuk kompos, pupuk kompos TKS (tandan kosong kelapa sawit + sampah restoran) dan JRM (jerami padi + sampah pasar) masing-masing $25 \mathrm{~g} \mathrm{polibag}^{-1}$ dan faktor kedua dosis pupuk NPK (A) terdiri atas $\left(0,12.5\right.$ dan 25) g tanaman ${ }^{-1}$. Variabel yang diamati yaitu tinggi tanaman, diameter batang, umur berbunga, umur panen, panjang buah dan bobot buah per tanaman. Data yang diperoleh dari pengamatan dianalisis secara statistik dengan menggunakan sidik ragam dan dilanjutkan dengan Duncan Multiple Range Test pada taraf 5\%. Hasil penelitian menunjukkan aplikasi pupuk kompos dan penambahan NPK tidak berbeda nyata terhadap variabel tinggi tanaman, panjang buah dan berat buah tanaman ${ }^{-1}$, namun berbeda nyata terhadap variabel diameter batang, umur panen dan umur berbunga tanaman cabai.
\end{abstract}

Kata kunci: dosis, hasil, NPK, pertumbuhan tanaman.

${ }^{1}$ Jurusan Agroteknologi, Fakultas Pertanian, Universitas Riau

Kampus Bina Widya Km 12,5 Kelurahan Simpang Baru Kecamatan Tampan Pekanbaru, Riau 28291, Indonesia

${ }^{2}$ Mahasiswa Jurusan Agroteknologi, Fakultas Pertanian, Universitas Riau

Kampus Bina Widya Km 12,5 Kelurahan Simpang Baru Kecamatan Tampan Pekanbaru, Riau 28291, Indonesia

Emai: hapsohdin@yahoo.co.id(*penulis korespondensi) 


\section{PENDAHULUAN}

Cabai merah (Capsicum annuum L.) termasuk ke dalam tanaman hortikultura kelompok sayuran buah yang memiliki nilai ekonomis yang cukup tinggi. Produksi cabai besar segar dengan tangkai tahun 2014 di Riau sebesar 9355 ton dengan luas panen cabai besar sebesar 1878 ha dan rata-rata produktivitas 4.98 ton $\mathrm{ha}^{-1}$. Dibandingkan dengan tahun 2013, terjadi kenaikan produksi sebesar 266 ton (2.93\%). Kenaikan ini disebabkan kenaikan luas panen sebesar 30 ha $(1.62 \%)$ dan kenaikan produktivitas sebesar 0.06 ton hektar ${ }^{-1}$ (1.28\%) (BPS, 2015).

Pengembangan cabai merah bertujuan meningkatkan produktivitas tanaman cabai guna memenuhi permintaan konsumen yang terus meningkat setiap tahun sejalan dengan meningkatnya jumlah penduduk dan berkembangnya industri yang membutuhkan bahan baku cabai. Salah satu upaya untuk meningkatkan produksi tanaman cabai dengan cara mengolah lahan secara tepat agar kesuburan tanah tetap terjaga. Pemupukan merupakan salah satu tindakan pemeliharaan tanaman yang utama untuk mendapatkan pertumbuhan yang optimal.

Pupuk ialah bahan yang diberikan ke dalam tanah baik yang organik maupun anorganik guna mencukupi kebutuhan hara yang diperlukan tanaman. Oleh karena itu perlu adanya penambahan bahan organik sebagai upaya meningkatkan ketersediaan $\mathrm{N}$, memperbaiki kualitas tanah dan memperbaiki sifat fisik, kimia dan biologi tanah. Karena bahan organik sendiri merupakan sumber koloid organik yang memiliki banyak keunggulan seperti mampu menyediakan hara makro dan mikro, dapat menghelat unsur logam yang bersifat racun, meningkatkan kapasitas menyangga air, meningkatkan nilai KTK, merupakan sumber energi bagi aktivitas organisme tanah, serta bersifat ramah lingkungan karena berasal dari residu makhluk hidup dan limbah pertanian seperti jerami padi dan kulit kakao atau limbah peternakan seperti kotoran unggas (Naniratih, 2013). Hasil penelitian Zulfan (2015), menunjukkan bahwa kompos TKKS yang dicampur dengan sampah restoran mengandung unsur hara nitrogen $1.23 \%$, fosfor $0.24 \%$ dan kalium $0.59 \%$, sedangkan kompos dari jerami padi yang dicampur sampah pasar mengandung unsur hara yaitu nitrogen $1.12 \%$, fosfor $0.23 \%$ dan kalium $0.60 \%$. Hasil penelitian Hapsoh dan Gusmawartati (2015) menunjukkan bahwa kompos tandan kosong kelapa sawit memiliki kandungan N 2.09\%, P $0.38 \%$, K $2.51 \%$ dan C-organik $39.01 \%$. Pupuk organik yang diberikan dalam budidaya tanaman cabai merah dapat berupa pupuk kompos dari limbah pertanian (tandan kosong kelapa sawit dan jerami padi) dan sampah kota organik (sampah restoran dan sampah rumah tangga), sedangkan pupuk anorganik yang diberikan yakni NPK. Tanaman cabai membutuhkan pupuk kandang 20 ton/ha dan NPK Mutiara 16:16:16 antara $200-250 \mathrm{~kg} / \mathrm{ha}$ yang diberikan pada minggu pertama setelah tanam dengan cara ditugal (Modifikasi Balittra, 2015). Tujuan penelitian ini untuk mengetahui pertumbuhan dan hasil tanaman cabai (Capsicum annuum L.) terhadap aplikasi pupuk kompos dan pupuk anorganik.

\section{BAHAN DAN METODE}

Penelitian dilaksanakan di Kebun Penelitian Jalan Melati, Panam dan Laboratorium Tanah Fakultas Pertanian Universitas Riau Kampus Bina Widya Km 12.5 Kelurahan Simpang Baru, Kecamatan Tampan, Pekanbaru. Penelitian dilaksanakan mulai dari bulan September 2015 sampai Maret 2016. Penelitian dilakukan secara percobaan faktorial yang disusun dalam rancangan acak lengkap (RAL), faktor 1 yaitu pupuk kompos dan faktor 2 yaitu dosis pupuk NPK.

Faktor 1 terdiri atas 3 taraf yaitu $\mathrm{K}_{0}=$ Tanpa pupuk kompos, $\mathrm{K}_{1}=$ Pupuk kompos TKS (tandan kosong kelapa sawit + sampah restoran) $25 \mathrm{~g}_{\text {polibag }}{ }^{-1}, \mathrm{~K}_{2}=$ Pupuk kompos JRM (jerami padi + sampah pasar) 25 g polibag $^{-1}$. Faktor 2 terdiri atas 3 taraf yaitu $\mathrm{A}_{0}=$ Tanpa pupuk NPK, $A_{1}=$ Pupuk NPK $1 / 2$ dosis anjuran (12.5 $\left.\mathrm{g} \mathrm{tanaman}^{-1}\right), \mathrm{A}_{2}=$ Pupuk NPK 1 dosis anjuran $\left(25 \mathrm{~g} \operatorname{tanaman}^{-1}\right)$. Masing-masing kombinasi diulang sebanyak 3 kali ulangan, sehingga terdapat 27 unit percobaan. Setiap unit percobaan terdiri atas 2 tanaman, sehingga total tanaman 54 tanaman. Data yang diperoleh dianalisis secara statistik menggunakan analisis ragam atau Analysis of Variance (ANOVA) dan dilanjutkan dengan Duncans New Multiple Range Test (DNMRT) pada taraf $5 \%$. 
Tabel 1. Tabel perlakuan pemberian pupuk NPK pada tanaman cabai

\begin{tabular}{ccccc}
\hline $\begin{array}{c}\text { Pemberian Dosis Pupuk NPK } \\
\left(\mathrm{g} \mathrm{tanaman}^{-1}\right)\end{array}$ & \multicolumn{3}{c}{ Tahap Pemberian } & Total \\
\cline { 2 - 4 }$\left(\mathrm{g} \mathrm{tanaman}^{-1}\right)$
\end{tabular}

Pupuk kompos TKS dan JRM menggunakan dekomposer mikroorganisme selulolitik dan diperkaya dengan pelarut $\mathrm{P}$ dan penambat N (Husnah, 2015). Pemberian pupuk kompos diberikan satu kali masing-masing 25 g polibag $^{-1}$ diberikan sebagai pupuk dasar kemudian didiamkan selama 4 hari sebelum penanaman. Pupuk NPK diberikan 3 kali pada umur 0,1 dan 2 bulan setelah tanam. Pemberian NPK dapat dilihat pada Tabel 1. Pupuk NPK diberikan pada tanaman dengan cara tugal di sekeliling tanaman dengan kedalaman lebih kurang $5 \mathrm{~cm}$ dengan jarak $6 \mathrm{~cm}$ dari tanaman.

Benih cabai yang dibudidayakan merupakan cabai keriting Varietas CA 237 tipe Sumatra dari produsen benih Bintang Asia. Penyemaian dilakukan menggunakan wadah semai, kemudian diisi media semai berupa tanah, pupuk kandang dan sekam padi dengan perbandingan 1:1:1. Sebelum penanaman media disiram hingga basah dan dilanjutkan dengan penanaman benih yang telah direndam dalam air hangat kuku selama 4 jam. Selanjutnya benih ditanam sebanyak 1 benih pada setiap wadah dengan kedalaman lebih kurang $0.5 \mathrm{~cm}$ lalu tutup kembali dengan tanah halus. Penyiraman pada persemaian dilakukan pada pagi dan sore hari.

Setelah bibit berumur 6 minggu di penyemaian, dilakukan penanaman pada sore hari pada saat cuaca tidak terlalu panas dengan cara mengeluarkan bibit dari wadah semai dan bibit ditanam dengan kedalaman lebih kurang $10 \mathrm{~cm}$ dan setiap polibag berukuran $30 \mathrm{~cm} \mathrm{x}$ $40 \mathrm{~cm}$ ditanam 1 bibit, dengan media tanam 10 $\mathrm{kg}$ polibag $^{-1}$.

Variabel pengamatan meliputi tinggi tanaman, diameter batang, umur berbunga, umur panen, panjang buah dan bobot buah per tanaman. Tinggi tanaman diukur mulai dari pangkal batang sampai titik tumbuh dari permukaan tanah. Tinggi tanaman diukur pada saat tanaman telah berbunga. Pengamatan diameter batang dilakukan dengan cara mengukur diameter batang tanaman pada posisi $5 \mathrm{~cm}$ dari permukaan tanah dengan menggunakan jangka sorong. Pengamatan umur berbunga dilakukan dengan cara menghitung jumlah hari yang dibutuhkan tanaman untuk berbunga mulai saat tanam hingga munculnya bunga pertama sampai seluruh populasi tanaman telah berbunga. Pengamatan umur panen dilakukan dengan cara menghitung jumlah hari setelah tanam sampai seluruh populasi tanaman telah berwarna merah pada percabangan pertama. Pengamatan panjang buah dilakukan dengan cara mengukur dari pangkal buah sampai ujung buah pada $25 \%$ buah cabai dari tanaman sampel kemudian dihitung rata-ratanya. Bobot buah per tanaman dihitung secara kumulatif dari seluruh buah pada setiap tanaman dengan cara menimbang seluruh tanaman sampel dan menjumlahkan bobot buah setiap kali panen sampai panen terakhir

\section{HASIL DAN PEMBAHASAN}

Hasil penelitian (Tabel 2) menunjukkan bahwa tinggi tanaman cabai pada perlakuan kompos JRM dan kompos TKS ditambah NPK yaitu berkisar $42.9 \mathrm{~cm}-60.3 \mathrm{~cm}$. Hasil penelitian Hapsoh dan Gusmawartati (2015) menunjukkan bahwa kompos jerami padi memiliki kandungan $\mathrm{N} 1.92 \%, \mathrm{P} 0.36 \%, \mathrm{~K}$ $2.57 \%$ dan C-organik $29.73 \%$. Kandungan $\mathrm{K}$ dalam kompos jerami padi berfungsi meningkatkan pertumbuhan tanaman. Pemupukan $\mathrm{K}$ berpengaruh signifikan dengan pola linear terhadap tinggi tanaman (Widyanti dan Susilo, 2015). Hulopi (2006) menyatakan bahwa pupuk NPK dapat meningkatkan pertumbuhan terutama tinggi tanaman, diduga karena peranan dari masing-masing pupuk $\mathrm{N}$, $\mathrm{P}$, dan $\mathrm{K}$ yang dapat merangsang pertumbuhan vegetatif tanaman.

Diameter batang tanaman cabai terbesar terdapat pada perlakuan tanpa kompos + NPK $25 \mathrm{~g}$ yakni $0.8 \mathrm{~cm}$, pemberian perlakuan tanpa kompos + tanpa NPK menunjukkan diameter batang terkecil yaitu $0.5 \mathrm{~cm}$. Kombinasi perlakuan tanpa kompos + NPK $25 \mathrm{~g}$ berbeda nyata terhadap kombinasi perlakuan tanpa 
kompos + tanpa NPK, namun berbeda tidak nyata terhadap perlakuan lainnya. Tabel 2 menunjukkan semakin meningkat dosis pupuk NPK yang diberikan menunjukkan peningkatan diameter batang tanaman cabai (tanpa pemberian bahan organik).

Data pada Tabel 3 menunjukkan bahwa umur berbunga dengan pemberian perlakuan pupuk kompos TKS 25 + tanpa NPK berbeda nyata dengan pemberian perlakuan tanpa kompos + NPK $12.5 \mathrm{~g}$, namun berbeda tidak nyata terhadap perlakuan lainnya. Umur berbunga tanaman cabai tercepat terdapat pada perlakuan pupuk kompos TKS $25 \mathrm{~g}+$ tanpa NPK 12.5 g yaitu 15.3 HST sedangkan umur berbunga terlama terdapat pada perlakuan tanpa kompos + NPK 12.5 g yaitu 24.3 HST. Pemberian kompos TKS $25 \mathrm{~g}+$ tanpa NPK menunjukkan umur berbunga tercepat yaitu
15.3 HST, namun tidak menjamin bahwa umur berbunga tercepat juga akan menunjukkan umur panen tercepat.

Tabel 3 menunjukkan bahwa umur panen tercepat terdapat pada perlakuan kompos TKS 25 g + NPK 12.5 g yaitu 52.0 HST. Lebih cepatnya umur panen pada perlakuan kompos TKS $25 \mathrm{~g}+$ NPK $12.5 \mathrm{~g}$ disebabkan karena unsur hara kalium pada kompos TKS lebih tersedia dan dapat dimanfaatkan oleh tanaman cabai. Banyaknya jumlah unsur $\mathrm{K}$ dalam tanah dan bertambahnya waktu akan berpengaruh terhadap kadar $\mathrm{K}$ tersedia di dalam tanah, sehingga dapat meningkatkan serapan $\mathrm{K}$ oleh tanaman pada akhirnya akan berpengaruh terhadap biomassa produksi tanaman cabai (Widowati et al., 2007).

Tabel 2. Pertumbuhan tanaman cabai dengan pemberian kompos dan pupuk NPK

\begin{tabular}{lcc}
\hline Perlakuan & $\begin{array}{c}\text { Tinggi tanaman } \\
(\mathrm{cm})\end{array}$ & $\begin{array}{c}\text { Diameter batang } \\
(\mathrm{cm})\end{array}$ \\
\hline Tanpa kompos + tanpa NPK & $51.4 \mathrm{a}$ & $0.5 \mathrm{~b}$ \\
Tanpa kompos + NPK 12.5 g & $42.9 \mathrm{a}$ & $0.6 \mathrm{ab}$ \\
Tanpa kompos + NPK 25 g & $58.6 \mathrm{a}$ & $0.8 \mathrm{a}$ \\
Kompos TKS 25 g + tanpa NPK & $54.1 \mathrm{a}$ & $0.6 \mathrm{ab}$ \\
Kompos TKS 25 g + NPK 12.5 g & $46.5 \mathrm{a}$ & $0.7 \mathrm{ab}$ \\
Kompos TKS 25 g + NPK 25 g & $54.3 \mathrm{a}$ & $0.7 \mathrm{ab}$ \\
Kompos JRM 25 g + tanpa NPK & $48.6 \mathrm{a}$ & $0.6 \mathrm{ab}$ \\
Kompos JRM 25 g + NPK 12.5 g & $60.3 \mathrm{a}$ & $0.8 \mathrm{ab}$ \\
Kompos JRM 25 g + NPK 25 g & $52.0 \mathrm{a}$ & $0.7 \mathrm{ab}$ \\
\hline
\end{tabular}

Keterangan: Angka-angka yang diikuti oleh huruf yang berbeda pada kolom yang sama adalah berbeda nyata pada uji DNMRT taraf $5 \%$.

Tabel 3. Hasil tanaman cabai dengan pemberian kompos dan pupuk NPK

\begin{tabular}{lcccc}
\hline Perlakuan & $\begin{array}{c}\text { Umur } \\
\text { Berbunga } \\
(\text { HST })\end{array}$ & $\begin{array}{c}\text { Umur } \\
\text { Panen } \\
(\mathrm{HST})\end{array}$ & $\begin{array}{c}\text { Panjang } \\
\text { Buah } \\
(\mathrm{cm})\end{array}$ & $\begin{array}{c}\text { Bobot Buah per } \\
\text { Tanaman } \\
(\mathrm{g})\end{array}$ \\
\hline Tanpa kompos + tanpa NPK & $18.6 \mathrm{ab}$ & $89.0 \mathrm{a}$ & $8.9 \mathrm{a}$ & $38.2 \mathrm{a}$ \\
Tanpa kompos + NPK 12.5 g & $24.3 \mathrm{a}$ & $101.3 \mathrm{a}$ & $7.6 \mathrm{a}$ & $42.9 \mathrm{a}$ \\
Tanpa kompos + NPK 25 g & $18.6 \mathrm{ab}$ & $84.0 \mathrm{ab}$ & $9.9 \mathrm{a}$ & $118.4 \mathrm{a}$ \\
Kompos TKS 25 g + tanpa NPK & $15.3 \mathrm{~b}$ & $77.3 \mathrm{ab}$ & $9.1 \mathrm{a}$ & $72.9 \mathrm{a}$ \\
Kompos TKS 25 g + NPK 12.5 g & $21.0 \mathrm{ab}$ & $52.0 \mathrm{~b}$ & $6.3 \mathrm{a}$ & $88.4 \mathrm{a}$ \\
Kompos TKS 25 g + NPK 25 g & $22.3 \mathrm{ab}$ & $89.6 \mathrm{a}$ & $9.1 \mathrm{a}$ & $52.4 \mathrm{a}$ \\
Kompos JRM 25 g + tanpa NPK & $18.6 \mathrm{ab}$ & $85.3 \mathrm{ab}$ & $8.9 \mathrm{a}$ & $76.5 \mathrm{a}$ \\
Kompos JRM 25 g + NPK 12.5 g & $18.6 \mathrm{ab}$ & $93.3 \mathrm{a}$ & $8.7 \mathrm{a}$ & $114.6 \mathrm{a}$ \\
Kompos JRM 25 g + NPK 25 g & $17.0 \mathrm{ab}$ & $86.6 \mathrm{a}$ & $7.5 \mathrm{a}$ & $85.6 \mathrm{a}$ \\
\hline Kem
\end{tabular}

Keterangan: Angka-angka yang diikuti oleh huruf yang berbeda pada kolom yang sama adalah berbeda nyata pada uji DNMRT taraf 5\%. Koefisien keragaman (\%) untuk umur berbunga 20.77, umur panen 21.35, panjang buah 28.93 dan bobot buah per tanaman 66.50 . 
Menurut penelitian yang dilakukan Golcz et al. (2012) dibandingkan tanaman hortikultura lain, cabai memiliki kebutuhan terbesar untuk kalium (40\%) dan nitrogen (31\%) dalam kaitannya dengan jumlah total nutrisi yang diserap. Penelitian pada tanaman sayuran termasuk cabai, hasil respons terhadap kalium sangat penting bagi kualitas tanaman. Sebagian besar petani menggunakan terlalu banyak atau terlalu sedikit pupuk $\mathrm{K}$ yang mengakibatkan turunnya kualitas dan kuantitas tanaman (Ortas, 2013).

Perlakuan pemberian kompos TKS $25 \mathrm{~g}$ + NPK 12.5 g diketahui mengandung unsur hara $\mathrm{N}, \mathrm{P}$, dan $\mathrm{K}$ yang cukup seimbang. Sutrisna dan Yanto (2014) menyatakan bahwa pemberian $\mathrm{N}$ yang cukup, menjamin pertumbuhan yang baik, hasil panen yang lebih tinggi dan buah berkembang penuh. Unsur $\mathrm{P}$ banyak berpengaruh terhadap pembungaan dan perkembangannya, kekerasan buah, warna buah, kandungan vitamin dan mempercepat pematangan buah. Penggunaan pupuk $\mathrm{K}$ meningkatkan kandungan gula, kandungan vitamin, kandungan asam total serta menambah jumlah buah yang dipanen, sehingga perlakuan kombinasi kompos TKS 25 $\mathrm{g}+$ NPK $12.5 \mathrm{~g}$ memiliki umur panen tercepat.

Data pada Tabel 3 menunjukkan bahwa seluruh perlakuan tidak menyebabkan perbedaan terhadap panjang dan bobot buah per tanaman.

Bobot buah per tanaman tertinggi yaitu $118.4 \mathrm{~g}$ diperoleh pada perlakuan tanpa kompos + NPK 25 g. Hasil ini konsisten dengan hasil penelitian Ariani (2009), bahwa jumlah buah per tanaman dan bobot buah per tanaman semakin meningkat seiring dengan semakin tingginya dosis pupuk NPK (16:16:16) yang diberikan pada tanaman cabai dengan dosis perlakuan terbaik yaitu 250 $\mathrm{kg} / \mathrm{ha}$.

Selain faktor pemupukan, pertumbuhan dan hasil tanaman cabai juga dipengaruhi oleh faktor cuaca. Curah hujan pada saat melakukan penelitian mencapai $1486.8 \mathrm{~mm}$, kelembaban $83.7 \%$, intensitas penyinaran $39.9 \%$ dan lama penyinaran 4.7 jam (Tabel 4). Tingginya curah hujan mempengaruhi kadar air tanah, aerasi tanah dan kelembaban udara. Begitu juga dengan kelembaban yang tinggi atau lebih dari $80 \%$ memacu pertumbuhan cendawan yang berpotensi menyerang dan merusak tanaman.

Cahaya matahari mempengaruhi pertumbuhan tanaman melalui lamanya penyinaran (panjang hari), juga berpengaruh terhadap pembungaan tanaman yang melalui tiga faktor yaitu kualitas, intensitas dan fotoperiodisme. Indonesia merupakan negara beriklim tropis, sehingga panjang siang dan malam hampir sama, yakni lama penyinaran mencapai 12 jam (Sutoyo, 2011).

Tanaman cabai termasuk ke dalam kelompok tanaman hari netral, yaitu tanaman yang dapat berbunga sepanjang tahun baik pada hari pendek ataupun hari panjang. Lama penyinaran pada saat melakukan penelitian rata-rata 4.7 jam hari ${ }^{-1}$. Cahaya matahari berpengaruh terhadap pertumbuhan tanaman melalui pembentukan klorofil, pembukaan stomata, pembentukan antocyanin (pigmen merah) perubahan suhu daun atau batang, penyerapan hara, permeabilitas dinding sel, transpirasi dan gerakan protoplasma.

Tabel 4. Data cuaca kota Pekanbaru bulan September 2015-Maret 2016

\begin{tabular}{lccccc}
\hline \multicolumn{1}{c}{ Bulan } & $\begin{array}{c}\text { Curah Hujan } \\
(\mathrm{mm} / \mathrm{bln})\end{array}$ & $\begin{array}{c}\text { Kelembaban } \\
(\%)\end{array}$ & $\begin{array}{c}\text { Suhu } \\
\left({ }^{0} \mathrm{C}\right)\end{array}$ & $\begin{array}{c}\text { Penyinaran } \\
(\%)\end{array}$ & $\begin{array}{c}\text { Penyinaran } \\
(\mathrm{Jam})\end{array}$ \\
\hline September & 60.0 & 82.0 & 27.0 & 22.0 & 2.6 \\
Oktober & 64.7 & 85.0 & 27.0 & 6.5 & 0.7 \\
November & 411.4 & 85.1 & 27.0 & 51.0 & 6.1 \\
Desember & 317.1 & 85.0 & 27.0 & 52.1 & 6.2 \\
Januari & 258.1 & 85.0 & 27.2 & 55.0 & 6.6 \\
Februari & 195.0 & 83.0 & 27.1 & 34.7 & 4.1 \\
Maret & 180.5 & 81.0 & 28.1 & 58.0 & 6.9 \\
\hline Total & 1486.8 & 83.7 & 27.2 & 39.9 & 4.7
\end{tabular}

Keterangan: Angka-angka yang diikuti oleh huruf yang berbeda pada kolom yang sama adalah berbeda nyata pada uji DNMRT taraf $5 \%$. 


\section{KESIMPULAN}

Aplikasi kompos terhadap pertumbuhan tanaman cabai dalam penelitian ini berpengaruh terhadap tinggi tanaman, umur berbunga dan umur panen, sedangkan aplikasi penambahan pupuk anorganik NPK berpengaruh terhadap diameter batang, panjang buah dan bobot buah per tanaman. Penambahan NPK lebih menyebabkan peningkatan hasil tanaman dibanding penambahan kompos. Aplikasi tanpa kompos + NPK 25 g menunjukkan diameter batang tertinggi $0.8 \mathrm{~cm}$, panjang buah tertinggi $9.9 \mathrm{~cm}$ dan bobot buah per tanaman tertinggi 118.4 HST. Pupuk kompos JRM $25 \mathrm{~g}+$ NPK $12.5 \mathrm{~g}$ memiliki tinggi tanaman mencapai 60.3 $\mathrm{cm}$ dan kompos TKS $25 \mathrm{~g}+$ tanpa NPK menunjukkan umur berbunga tercepat, yaitu 15.3 HST sedangkan kompos TKS $25 \mathrm{~g}+$ NPK 12.5 $\mathrm{g}$ menunjukkan umur panen tercepat yaitu 52.0 HST.

\section{UCAPAN TERIMA KASIH}

Ucapan terima kasih ditujukan kepada Kemristekdikti atas dukungan dana penelitian melalui Hibah Kompetensi (HIKOM) tahun 2014.

\section{DAFTAR PUSTAKA}

Ariani, E. 2009. Uji pupuk NPK 16:16:16 dan berbagai jenis mulsa terhadap hasil tanaman cabai (Capsicum annuиm L). J. Sagu. 8(1): 5-9.

[Balittra] Balai Penelitian Pertanian Lahan Rawa. 2015. Panduan Teknis Budidaya Cabai. http://balittra.litbang.pertanian.go.id/ [07 Juni 2016].

[BPS] Badan Pusat Statistik. 2015. Data produksi cabai Provinsi Riau. www.bps.go.id/getfile.php?news.htm. [04 April 2016].

Golzc, A., P. Kujawski, B. Markiewicz. 2012. Yielding of red pepper (Capsicum annuит L.) under the influence of varied potassium fertilization. J. Acta Scientiarum Polanorum-Hortorum Cultus. 11(4): 3-15.
Hapsoh, Gusmawartati. 2015. Pengkayaan pupuk organik dengan teknologi mikrob untuk mendukung pertanian terpadu yang berkelanjutan. LPPM Universitas Riau. Pekanbaru.

Hulopi, F. 2006. Pengaruh penggunaan pupuk kandang dan pupuk NPK terhadap pertumbuhan dan hasil tanaman kacang tanah. Buana Sains. 6(2): 165-170.

Husnah, A.U. 2015. Isolasi dan identifikasi serta uji potensi bakteri selulolitik asal kulit buah durian di Kota Pekanbaru. [Skripsi]. Fakultas Pertanian Universitas Riau. Pekanbaru.

Naniratih, I., M.B.B. Damanik, G. Sitanggang. 2013. Ketersediaan nitrogen pada tiga jenis tanah akibat pemberian tiga bahan organik dan serapannya pada tanaman jagung. J. Online Agroteknologi. 1(3): 479-488.

Ortas, I. 2013. Influences of nitrogen and potassium fertilizer rates on pepper and tomato yield and nutrient uptake under field conditions. Academic Journals. 8(23): 1048-1055.

Sutrisna, N., S. Yanto. 2014. Uji formula NPK pada pertanaman cabai rawit dataran tinggi Lembang, Jawa Barat. Agros. 16(1): 172-181.

Sutoyo. 2011. Foto periodisme dan pembungaan tanaman. Buana Sains. 11(2): 137-144.

Widowati, Astutik, E. Nogo. 2007. Efisiensi pemupukan $\mathrm{K}$ dengan bokashi tinja pada cabai besar. Buana Sains. 7(2): 177-185.

Widyanti, A.S., A.D. Susila. 2015 Rekomendasi pemupukan kalium pada budidaya cabai merah besar (Capsicum annuит L.) di inceptisols Dramaga. J. Hort. Indonesia. 6(2): 65-74.

Zulfan, M. 2015. Mutu kompos dari kombinasi bahan baku kering sampah organik dan limbah pertanian. [Skripsi] Fakultas Pertanian Universitas Riau, Pekanbaru. 